\title{
EVALUATION OF THE CHITOSAN-COATING EFFECTIVENESS ON A DENTAL TITANIUM ALLOY IN TERMS OF MICROBIAL AND FIBROBLASTIC ATTACHMENT AND THE EFFECT OF AGING
}

\author{
OCENA UČINKOVITOSTI NANOSA HITOZANA NA \\ OPRIJEMANJE MIKROBOV IN FIBROBLASTOV NA DENTALNI \\ TITANOVI ZLITINI TER NA POJAV STARANJA
}

\author{
Ulku Tugba Kalyoncuoglu¹, Bengi Yilmaz ${ }^{2}$, Serap Gungor ${ }^{3}$, Zafer Evis ${ }^{4}$, \\ Pembegul Uyar ${ }^{5,6}$, Gulcin Akca ${ }^{7}$, Gulay Kansu ${ }^{8}$ \\ ${ }^{1}$ Balgat Oral and Dental Health Center, Baris Manco Street 22, 06520 Ankara, Turkey \\ 2Middle East Technical University, Department of Biomedical Engineering, 06800 Ankara, Turkey \\ ${ }^{3}$ Yuzuncu Yil University, Department of Mechanical Engineering, 65080 Van, Turkey \\ ${ }^{4}$ Middle East Technical University, Department of Engineering Sciences, 06800 Ankara, Turkey \\ ${ }^{5}$ Selcuk University, Department of Biology, 4207 Konya, Turkey \\ ${ }^{6}$ Selcuk University, Advanced Technology Research and Application Center, 4207 Konya, Turkey \\ ${ }^{7}$ Gazi University, Faculty of Dentistry, Department of Microbiology, 06500 Ankara, Turkey \\ ${ }^{8}$ Ankara University, Faculty of Dentistry, Department of Prosthodontics, 06500 Ankara, Turkey \\ ulkutugbaterzi@gmail.com \\ Prejem rokopisa - received: 2014-09-23; sprejem za objavo - accepted for publication: 2015-01-08
}

doi:10.17222/mit.2014.239

The aim of this study was to obtain a biocompatible and antimicrobial implant surface by coating Ti6Al4V with chitosan which can be used to create a smooth transmucosal region for a faster and better wound healing and an increased bioactivity. Ti6Al4V plates were first abraded and ultrasonically cleaned and then coated with chitosan. In order to simulate the conditions of an oral environment, a group of coated plates were treated in a thermocycle apparatus. The coatings were evaluated with SEM, EDS, XRD and FTIR spectroscopy. The fibroblastic cell behavior was determined using HGF-1 cells. P. gingivalis was used to assess the effectiveness of chitosan as an antimicrobial coating.

It can be said that the Ti6Al4V plates were successfully coated with chitosan, indicated by the presence of the $\mathrm{C}$, $\mathrm{H}$ and $\mathrm{O}$ elements in the EDS results. There were no significant differences between the XRD patterns of the coated and uncoated plates; however, the characteristic bands of chitosan were observed in the FTIR patterns of both the coated and aged samples. The fibroblast-cell attachment and proliferation were enhanced while the bacterial proliferation was inhibited by the chitosan coating. Chitosan was shown to be a biologically useful material that can be used as the coating material for transmucosal regions of dental implants.

Keywords: chitosan coating, dental implants, Ti6Al4V, HGF-1, P. gingivalis

Namen te študije je bil dobiti biokompatibilno in antimikrobno površino implantata z nanosom hitozana na Ti6Al4V, ki je primeren za gladko transmukozno področje, za hitrejše in boljše celjenje ran ter povečano bioaktivnost. Pri ploščah Ti6Al4V je bila najprej povečana hrapavost, nato so bile očiščene z ultrazvokom, potem pa je bil nanesen hitozan. Da bi simulirali razmere $\mathrm{v}$ ustih, je bila skupina plošč obdelana v napravi za termocikliranje. Nanosi so bili ocenjeni s SEM-, EDS-, XRD- in FTIR-spektroskopijo. Vedenje celic fibroblastov je bilo določeno z uporabo celic HGF-1. P. gingivalis je bil uporabljen za oceno učinkovitosti hitozana kot protimikrobnega nanosa.

Lahko trdimo, da so bile plošče Ti6Al4V uspešno prekrite s hitozanom, kar potrjuje prisotnost elementov $\mathrm{C}$, $\mathrm{H}$ in $\mathrm{O}$ v EDS-rezultatih. Ni bilo opažene večje razlike pri rentgenski analizi vzorcev z nanosom in brez nanosa, vendar so bili opaženi karakteristični signali hitozana pri FTIR-analizi vzorcev tako pri vzorcih z nanosom kot tudi pri staranih vzorcih. Oprijemanje in širjenje fibroblastičnih celic je bilo pospešeno, medtem ko je nanos hitozana zaviral širjenje bakterij. Pokazalo se je, da je hitozan biološko koristen material, ki ga je mogoče uporabiti za nanos na transmukozna področja dentalnih implantatov.

Ključne besede: nanos hitozana, dentalni implantati, Ti6Al4V, HGF-1, P. gingivalis

\section{INTRODUCTION}

Peri-implantitis, defined as an inflammatory reaction of the tissues surrounding a dental implant to a loss of the supporting bone, ${ }^{1}$ is still the major challenge for the implant dentistry. It is known that the interface between an implant and the healthy soft tissue is similar to the one involving natural teeth. ${ }^{2}$ A peri-implant soft-tissue cuff has to provide the same functions with the peridental gingiva, such as inflammatory and immunological defenses, growth factors and cytokine productions, filtering the seal around a tooth, an implant or prosthetic. ${ }^{3}$

Titanium (Ti), which is currently used for the production of dental implants, has remarkable properties, such as a good corrosion resistance, a very good biovcompatibility and a high strength-to-weight ratio. A dioxide (or trioxide) layer that is a few nanometers thick (3-5 nm) spontaneously forms on the Ti surface. This is the layer that the biological fluids and tissues are in 
contact with when $\mathrm{Ti}$ implants are inserted into the body. ${ }^{4}$ However, Ti is not able to function as an anti-microbial agent and, therefore, it cannot prevent the periimplant infections. ${ }^{5}$

Surface modifications of implants with bioactive coatings stimulating the bone-cell attachment and growth is one way to increase the osseointegration and help stabilize the implant. ${ }^{6}$ Furthermore, in recent years, in order to decrease the bacterial activity around the Ti implants, studies focused on coating the transmucosal components with antimicrobial and biocompatible coating materials which are also efficient at wound healing and cellular attachment. On the other hand, the adhesion of gingival and epithelial cells is a desirable situation, providing a seal around the transmucosal component; however, a bacterial adhesion, which can provoke a breakdown of the attachment, is not wanted. ${ }^{4}$

For these kinds of applications, chitosan has many advantages, such as biocompatibility, antimicrobial efficiency and cheapness. It is a chitin-derived natural polymer produced by a deacetylation reaction. Chitin is mainly found in the exoskeleton of crustaceans and also in some fungi. Chitosan has been used in many biomedical applications including wound healing, skin grafting, homeostasis, hemodialysis, drug delivery, preventing dental plaque, calcium adsorption, etc. ${ }^{7}$

The objective of this study was to fabricate and characterize chitosan-coated Ti6Al4V plates. It is hypothesized that a chitosan coating would help with the human-gingival-fibroblast (HGF) attachment and antimicrobial effects. The influence of aging which simulates an oral environment was investigated in vitro as well.

\section{MATERIALS AND METHODS}

Titanium-alloy (Ti6Al4V) plates with dimensions of $20 \mathrm{~mm} \times 20 \mathrm{~mm} \times 2 \mathrm{~mm}$ were used in this study. The samples were divided into three groups: the control or un-treated Ti6Al4V $(n=5)$ (group 1), the chitosancoated Ti6Al4V $(n=5)$ (group 2) and the chitosancoated and aged Ti6Al4V $(n=5)$ (group 3). Before the coating process, the surfaces of the plates were airborne-particle abraded with $50 \mu \mathrm{m}$ aluminum-oxide particles for $10 \mathrm{~s}$ under $413.7 \mathrm{kPa}(60 \mathrm{psi})$, with a distance from the tip of $0.5 \mathrm{~mm}$, in a sandblaster (Heraeus Kulzer Combilabor, CL FSG 3, Germany). The aim of sandblasting was to increase the surface contact area and to obtain a higher surface roughness. All the samples were ultrasonically cleaned for $10 \mathrm{~min}$ in distilled water, $70 \%$ ethanol, acetone, $70 \%$ ethanol and distilled water sequence, respectively.

\subsection{Chitosan coating}

The coating procedure was performed as described by Yuan et al. ${ }^{8}$ Firstly, the plates were submerged in a volume fraction water : ethanol 5\%:95\% solution. 3 -iso-cyanatopropyltriethoxysilane was added at a con- centration of $\varphi=2 \%$ for $10 \mathrm{~min}$ at room temperature while maintaining the $\mathrm{pH}$ at 4.5-5.5 with $\mathrm{NaOH}$ or acetic acid. The samples were rinsed with ethanol and treated at $110{ }^{\circ} \mathrm{C}$ for $10 \mathrm{~min}$ in a vacuum oven (Nüve EV 018, Turkey). The samples were submerged into a volume fraction $\varphi=2 \%$ gluteraldehyde solution at room temperature overnight and rinsed with distilled water. A mass fraction $1 \%$ acetic-acid solution (aqueous) and $1 \%$ chitosan (a medium molecular weight, Sigma Aldrich, Germany) in the acetic-acid solution were prepared. These solutions were mixed and stirred for $10 \mathrm{~min}$ and the resulting solution turned into a gel. The plates were submerged in this chitosan/acetic-acid solution at $4{ }^{\circ} \mathrm{C}$ overnight. The excess water was allowed to evaporate over $7 \mathrm{~d}$ (at ambient conditions).

The plates were briefly rinsed in $0.005 \mathrm{M} \mathrm{NaOH}$ followed by distilled water. After the coating process, a group of the coated plates (group 3) were treated with a thermocycle apparatus (Nüve, Turkey) to simulate a one-year oral environment. The aging process was performed for 1 week and the temperature of the water bath was alternated between $5-55^{\circ} \mathrm{C} .{ }^{9}$

The surface morphologies of the plates were observed using SEM (QUANTA 400F Field Emission SEM) at a voltage of $20 \mathrm{kV}$ and the chemical composition was determined with EDS using a $30 \mathrm{keV}$ ion beam. For the SEM observation the samples were coated with $5 \mu \mathrm{m}$ AuPd. The XRD structural analysis was performed using an Ultima-IV X-ray diffractometer (Riga$\mathrm{ku}$, Tokyo, Japan). The XRD was operated with a $\mathrm{Cu}-K_{\alpha}$ radiation $(40 \mathrm{kV} / 40 \mathrm{~mA})$ and spectra were collected in the $2 \theta$ range of $10^{\circ}$ to $80^{\circ}$ with a scan speed of $2^{\circ} \mathrm{min}^{-1}$. The surface functional groups of the coated samples were determined with a FTIR spectroscope (Bruker IFS $66 / \mathrm{s}$, Bruker Optics, Germany) in wavenumber regions of $3800 \mathrm{~cm}^{-1}$ to $300 \mathrm{~cm}^{-1}$.

\subsection{Cell culture and the MTT test}

Before the biological experiments, for sterilization, the samples were washed in $95 \%$ ethanol and placed under UV for $15 \mathrm{~min}$, rinsed twice with sterile demineralized water and PBS. The HGF-1 cells (ATCC, CRL-2014) were donated by the Ankara University Faculty of Veterinary Medicine. The cells were cultured in Dulbecco's Modified Eagle Medium (DMEM) supplemented with $10 \%$ of fetal-calf serum (FCS), $100 \mathrm{U} / \mathrm{mL}$ penicillin and $100 \mu \mathrm{g} / \mathrm{mL}$ streptomycin in a $\varphi=5 \% \mathrm{CO}_{2}$ incubator at $37{ }^{\circ} \mathrm{C}$ (all from Biochrom Ltd, Cambridge, $\mathrm{UK})$. The proliferation of the cells was determined with a MTT (3-(4.5-dimethylthiazol-2-yl)-2.5-diphenyl-tetrazolium salt) test assay (Sigma, St Louis, MO, USA) and the morphology of the cells was examined with SEM.

HGF-1 cells were seeded on the Ti6Al4V plates, placed onto 6-well plates, at a density of cells $4 \times 10^{5}$ $\mathrm{mL}^{-1}$. The cells were incubated in $5 \% \mathrm{CO}_{2}$ at $37{ }^{\circ} \mathrm{C}$ for $96 \mathrm{~h}$. The Ti6Al4V plates were moved onto new 6-well plates after $96 \mathrm{~h}$ of incubation, and fresh media were 
added. The media were then removed, a diluted MTT $(5 \mathrm{mg} / \mathrm{mL})$ solution was added into the wells and the incubation was continued in $5 \% \mathrm{CO}_{2}$ at $37{ }^{\circ} \mathrm{C}$ for $4 \mathrm{~h}$. After that, the incubation medium was removed and 400 $\mu \mathrm{L}$ of isopropanol with $0.04 \mathrm{~N} \mathrm{HCl}$ was added to each well in order to dissolve the resulting formazan crystals. The absorbance of the formazan product at $570 \mathrm{~nm}$ and $690 \mathrm{~nm}$ was measured with a microplate reader (Biotek Epoch, Germany). The experiment was repeated independently in triplicate.

\subsection{Cellular attachment and the morphology}

The surfaces were analyzed using SEM in order to determine the cellular attachment and morphology of the cells. The HGF-1 cells cultured for $96 \mathrm{~h}$ on the Ti6Al4V plates were washed twice with a $0.1 \mathrm{M}$ sodium-cacodylate buffer ( $\mathrm{pH} 7.4$ ), and the cells were fixed with $2.5 \%$ glutaraldehyde prepared in $0.1 \mathrm{M}$ sodium cacodylate for $1 \mathrm{~h}$ at room temperature. The excess glutaraldehyde solution was removed and the cells were rinsed twice in sterile distilled water and kept at $-80{ }^{\circ} \mathrm{C}$ overnight before lyophilization. After the cells were dried to a critical point, the samples were coated with AuPd. The fixed cells on the discs were observed with SEM (Zeiss LS-10, Germany). The SEM images were recorded at 500-times and 5000-times magnifications.

\subsection{Microbiological evaluation}

The microbiological processes were done in the Medical Microbiology Laboratory at the Gazi University, the Faculty of Dentistry. In order to assess the microbial inhibition, Porphyromonas gingivalis (ATCC 33277) was used and cultured in Columbia Broth (Merck, Germany) supplemented with vitamin $\mathrm{K}(1 \mu \mathrm{g} / \mathrm{mL})$, hemin $(5 \mu \mathrm{g} / \mathrm{mL})$ and $5 \%$ sheep blood in an automated anaerobic chamber (Electrotek, United Kingdom) at $37{ }^{\circ} \mathrm{C}$ for $3-5 \mathrm{~d}$ with an atmosphere of $10 \% \mathrm{H}_{2}, 10 \% \mathrm{CO}_{2}$ and $80 \% \mathrm{~N}_{2}$. The optical density of bacterial inoculum was adjusted to a $5 \times 10^{8}$ colony-forming unit per $\mathrm{mL}$ (cfu/mL) using a spectrophotometer (BioTek ELx800, USA) according to the turbidity of the McFarland standard.

The same bacterial inoculum was spread onto a Schaedler agar media (Merck, Germany) supplemented with vitamin $\mathrm{K}(1 \mu \mathrm{g} / \mathrm{mL})$, hemin $(5 \mu \mathrm{g} / \mathrm{mL})$ and $5 \%$ sheep blood in the automated anaerobic chamber (Electrotek, UK) and the Ti6Al4V samples, coated with chitosan, were embedded into the infected agar plates with chitosan-coated faces. Then, the plates were incubated at $37{ }^{\circ} \mathrm{C}$ in an atmosphere of $10 \% \mathrm{H}_{2}, 10 \% \mathrm{CO}_{2}$ and $80 \%$ $\mathrm{N}_{2}$ in the anaerobic chamber for 3-5 d. During the incubation period, the day after the incubation and every following day, a loopful of a sample was tested for the viability of the bacteria by culturing them on another Schaedler agar media, separately in the anaerobic chamber under the same conditions as mentioned before.
Then, the grown colonies of the bacteria were counted, calculated as cfu/mL and evaluated for the viability of the bacteria. All the samples were studied in triplicates in the experiment.

\section{RESULTS}

The SEM images of the uncoated, chitosan-coated and chitosan-coated and aged Ti6Al4V plates are given in Figure 1. As expected, the uncoated Ti6Al4V plate (Figures 1a and 1b) was observed to have a rougher surface than the coated plates.

A chitosan aggregate was identified in the SEM micrographs of the chitosan-coated and aged plate. The chitosan was homogeneously distributed on the sandblasted Ti6A14V surface and conserved to a degree after the aging process. The chitosan aggregate can be seen more clearly at a high magnification even on the aged plate (Figure 1f). From Figures 1c and 1d, it can be seen that the chitosan completely covered the Ti6Al4V substrate before the aging process was applied. The microcracks in the chitosan coating (Figure 1c) can be explained with the drying procedure in the ambient conditions. These cracks would have been prevented by freeze-drying the samples after the coating process. The coating was expected to be thicker than the chitosan phase on the aged plate due to the possible erosion
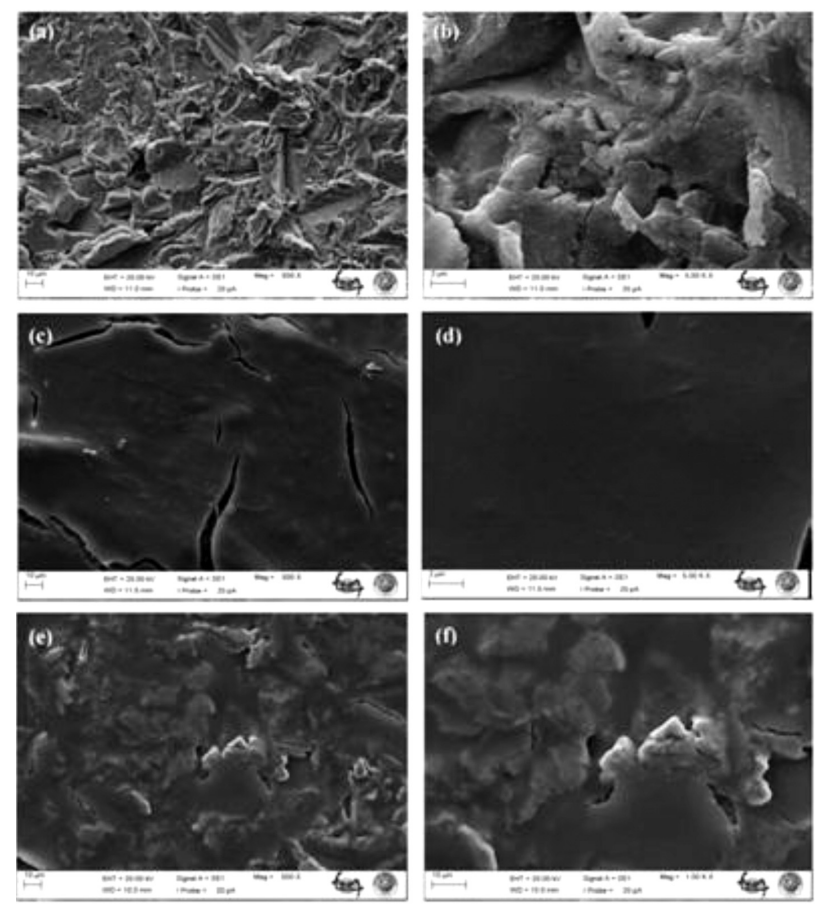

Figure 1: SEM images of Ti6A14V plates: a) uncoated, 500-times, b) uncoated, 5000-times, c) chitosan-coated, 500-times, d) chitosan-coated, 5000-times, e) chitosan-coated and aged, 500-times, f) chitosan coated and aged, 5000-times

Slika 1: SEM-posnetki Ti6Al4V plošč: a) brez nanosa, povečava 500-kratna, b) brez nanosa, 5000-kratna, c) nanos hitozana, 500-kratna, d) nanos hitozana, 5000-kratna, e) nanos hitozana in starano, 500kratna, f) nanos hitozana in starano, 5000-kratna 

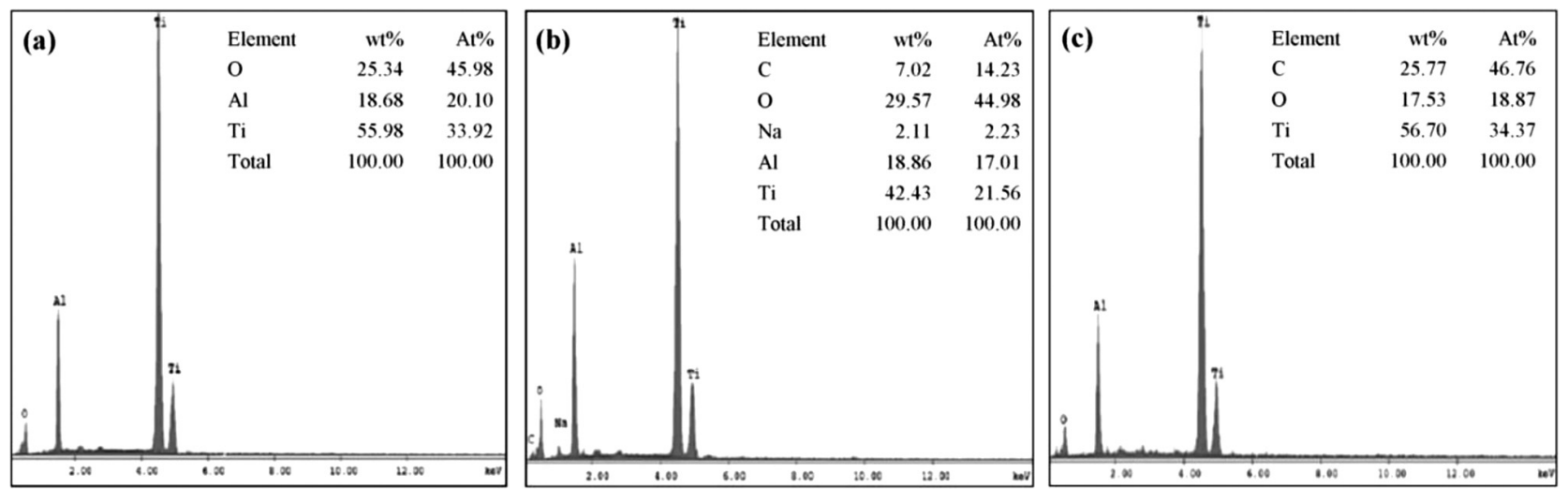

Figure 2: EDS spectra of Ti6Al4V plates: a) uncoated, b) chitosan-coated, c) chitosan-coated and aged

Slika 2: EDS-spektri Ti6A14V plošč: a) brez nanosa, b) z nanosom hitozana, c) z nanosom hitozana in starano

caused by the aging process. When Figures 1c to $1 \mathbf{f}$ are compared, it can be seen that the rough-surface morphology, completely covered with the chitosan coating, reappears in the aged plates.

EDS was used to identify the elements and obtain semi-quantitative compositional information from the surfaces of the plates. The EDS results for the surfaces of the uncoated, chitosan-coated and chitosan-coated and aged Ti6Al4V plates are given in Figure 2.

The EDS analysis confirms the presence of the chitosan coating with the detected $\mathrm{C}$ and $\mathrm{O}$ elements on the Ti6Al4V plates even after the aging process. Without chitosan, due to the chemical content of the substrate material, the $\mathrm{Ti}$ and $\mathrm{Al}$ elements were detected together with the $\mathrm{O}$ element. The EDS spectrum of the chitosancoated plate (Figure 2b) was observed to contain a low amount of the $\mathrm{Na}$ element.

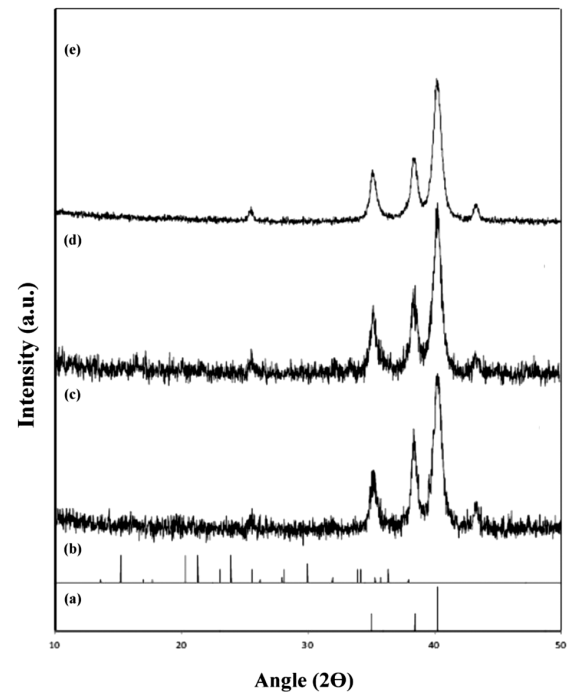

Figure 3: XRD patterns of: a) standard Ti (JCPDS \# 01-1197), b) chitosan (JCPDS \# 039-1894), c) uncoated Ti6Al4V plate, d) chitosancoated Ti6Al4V plate, e) chitosan-coated and aged Ti6Al4V plate Slika 3: Rentgenski posnetki vzorcev: a) Ti standard (JCPDS \# 01-1197), b) hitozan (JCPDS \# 039-1894), c) plošča Ti6Al4V brez nanosa, d) plošča Ti6Al4V z nanosom hitozana, e) plošča Ti6Al4V z nanosom hitozana in starana
The XRD patterns of the surfaces of the uncoated, chitosan-coated, chitosan-coated and aged Ti6Al4V plates are given, with the XRD peak positions of standard Ti and chitosan (Figure 3).

On Figures 3a and 3c, the substrate plates have the main standard Ti peaks at the $2 \theta$ values of $35.02^{\circ}, 38.44^{\circ}$ and $40.23^{\circ}$. The common XRD peaks at $25.42^{\circ}$ and $42.22^{\circ}$ were also attributed to the Ti6Al4V substrate. There were no distinct peaks of chitosan detected in the XRD patterns of both the coated or coated and aged plates.

The FTIR spectra of the surfaces of the chitosancoated and chitosan-coated and aged Ti6Al4V plates are given in Figure 4. The FTIR spectra of the chitosancoated Ti6Al4V plates show obvious differences after the aging process. If the FTIR spectrum of the coated and aged sample (Figure $\mathbf{4 b}$ ) is compared with the one that was only coated, it can be seen that there are two additional bands at $2921 \mathrm{~cm}^{-1}$ and $2851 \mathrm{~cm}^{-1}$ which belong to the $-\mathrm{CH}_{2}$ - and $-\mathrm{CH}_{3}$ stretching vibrations, respectively. ${ }^{10}$ In addition, the intensities of the FTIR bands were decreased after the aging process. In the FTIR spectra of the chitosan-coated and aged sample, the band

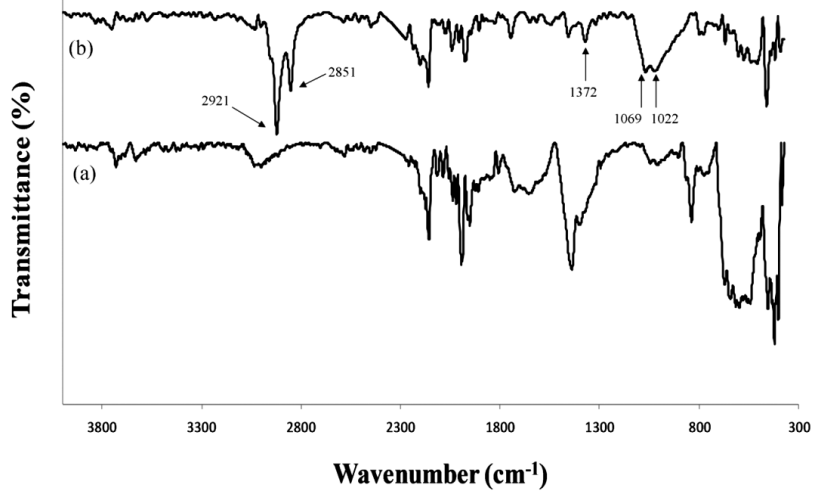

Figure 4: FTIR patterns of Ti6Al4V plates: a) chitosan-coated, b) chitosan-coated and aged

Slika 4: FTIR posnetka vzorcev Ti6Al4V-plošč: a) z nanosom hitozana, b) z nanosom hitozana in starano 


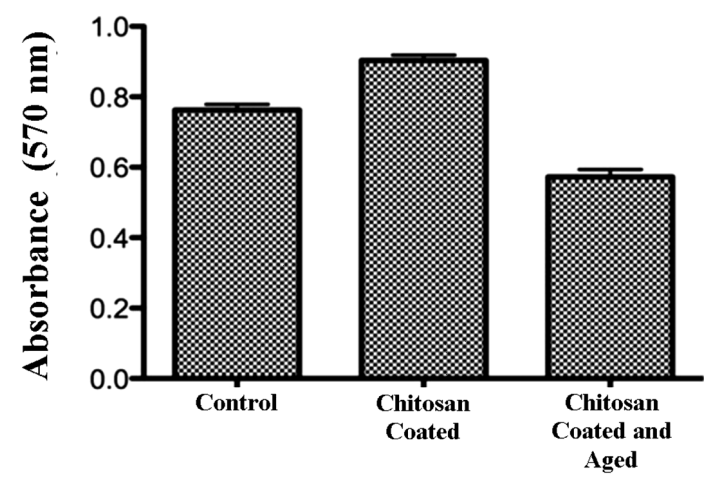

Figure 5: Survival/population of HGF-1 cells after $96 \mathrm{~h}$ of incubation on the control (untreated), chitosan-coated and chitosan-coated and aged Ti6Al4V plates. Data were expressed as the mean values (MV) of the \pm standard deviation (SD) of three independent experiments.

Slika 5: Preživela populacija celic HGF-1 po 96 h inkubacije na kontrolni plošči Ti6Al4V (brez nanosa), z nanosom hitozana in z nanosom hitozana ter staranju. Podatki za tri neodvisne preizkuse so prikazani kot srednja vrednost $(\mathrm{MV}) \pm$ standardna deviacija (SD).

at $1372 \mathrm{~cm}^{-1}$ was assigned to -NHCO of amide and the bands at $1069 \mathrm{~cm}^{-1}$ and $1022 \mathrm{~cm}^{-1}$ were ascribed to the saccharide structure. ${ }^{11}$

The cellular viability of the HGF-1 cells of both the coated and coated and aged Ti6Al4V plates was evaluated using a MTT assay. The absorbances of the formazan produced by metabolically active HGF-1 cells on the experimental groups are given in Figure 5.

The cell morphology, cytoskeletal structure and adhesion behavior of the HGF-1 cells were observed

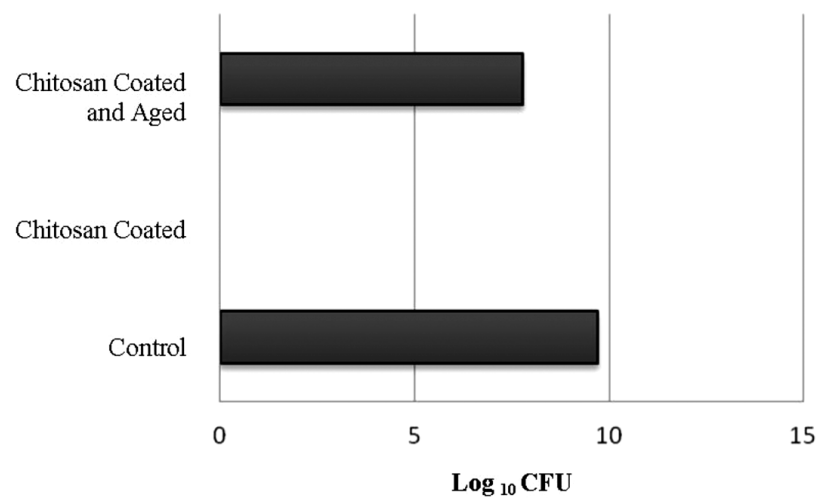

Figure 7: Number of viable $P$. gingivalis colonies (interpreted as $\lg _{10}$ ) Slika 7: Število živih kolonij $P$. gingivalis (prikazanih kot $\lg _{10}$ )

after $96 \mathrm{~h}$ of incubation on the control (untreated), chitosan-coated, and chitosan-coated and aged Ti6Al4V plates. The SEM micrographs, at two different magnifications, for each group are given in Figure 6.

In order to observe the inhibition effect of chitosan against the bacterial growth, the untreated Ti6Al4V plate (control), the chitosan-coated Ti6Al4V plate and the chitosan-coated Ti6Al4V plate after the ageing process were used as substrates. The numbers of viable $P$. gingivalis colonies proliferated on these substrates are given in Figure 7.

As can be seen from Figure 7, no $P$. gingivalis colonies were detected in the agar medium, on which the chitosan-coated samples were placed. On the other hand,
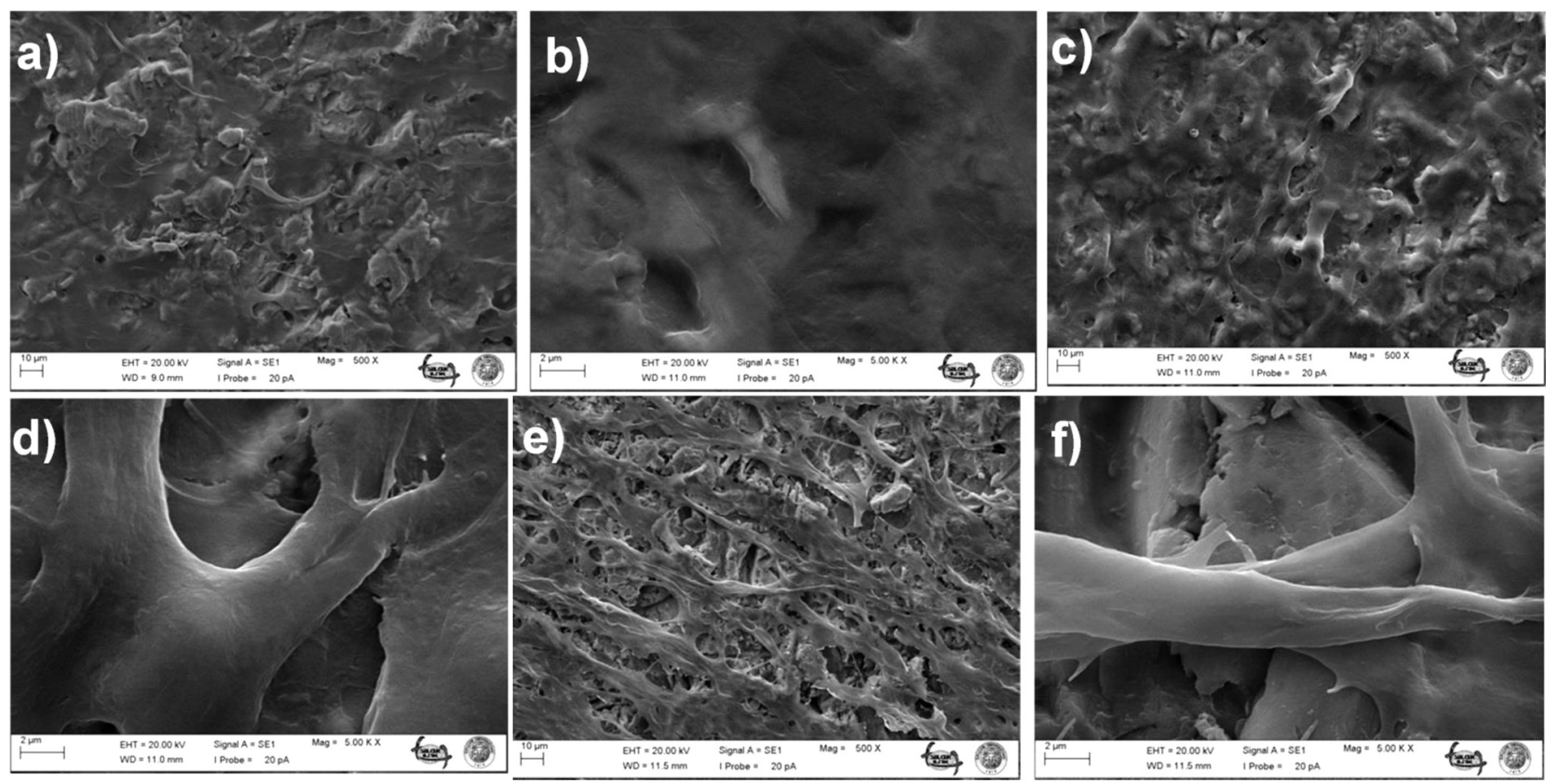

Figure 6: SEM micrographs of cultured human gingival fibroblast cells after $96 \mathrm{~h}$ of incubation on the Ti6Al4V plates: a), b) control (untreated), c), d) chitosan-coated, e), f) chitosan-coated and aged. Magnifications: 500-times (images on the left-hand side) and 5000-times (images on the right-hand side)

Slika 6: SEM-posnetki kultiviranih človeških gingivalnih fibroblastičnih celic po 96 h inkubacije na Ti6Al4V-ploščah: a), b) kontrolni (brez nanosa), c), d) z nanosom hitozana, e), f) z nanosom hitozana in starano. Povečave: 500-kratna (slike na levi strani) in 5000-kratna (slike na desni strani) 
the bacterial growth was detected in the agar medium for the chitosan-coated and aged Ti6Al4V plates; however, the growth was much smaller than in the agar medium for the untreated Ti6Al4V plates.

\section{DISCUSSION}

Following the definition of osseointegration as a close contact between the bone and $\mathrm{Ti}$ and its alloys at the bone level, ${ }^{12}$ the researchers focused on the surfacemodification methods and implant-body design.

The major purposes for modifying dental implant surfaces are to positively modulate the host/implant tissue responses, prevent a microorganism attachment, a bone destruction, and also a failure of the implant, and decrease the healing period for osseointegration. ${ }^{12}$ The aim of this study was to obtain an antibacterial coating for dental/craniofacial and orthopaedic implants and test the ability of the coating to promote the fibroblastic-cell growth before and after an aging process. For this purpose, chitosan, which is a biocompatible, biodegradable, antibacterial and inexpensive natural polymer with a good film-forming ability ${ }^{13}$, was applied on the Ti6Al4V substrate via silanization. The chitosan was successfully deposited on the plates, forming a uniform and yellowish transparent layer with some microcracks, possibly formed due to the ambient drying process.

The SEM micrographs revealed the existence of a chitosan layer on the plates even after the aging process. In addition, sandblasting increased the surface roughness and allowed a proper mechanical interlock with the coating. The elements belonging to the chitosan coating were detected with the EDS method on both the coated, and coated and aged plates. The presence of the oxygen $(\mathrm{O})$ element in the EDS measurements of the Ti6Al4V plates (Figure 2a) can be attributed to the $\mathrm{Al}_{2} \mathrm{O}_{3}$ grains embedded in the surface during sandblasting ${ }^{14}$ or the oxide layer naturally forming on Ti and its alloys. The sodium (Na) element, which was detected in the EDS spectra of the chitosan-coated plate, was thought to originate from the $\mathrm{NaOH}$ solution that was used to remove the remaining acetic acid after the coating process.

The XRD pattern of the chitosan is characteristic of an amorphous polymer ${ }^{15}$ and yields broad peaks. Consequently, in the chitosan-coated plates there were no distinctive differences when compared to the substrate material. However, in the FTIR spectra of the chitosancoated Ti6Al4V plates, characteristic bands of chitosan were observed and the aged sample showed obvious differences. The FTIR spectra showed molecular changes induced by the aging process. The main change observed was a decrease in the amide group $1372 \mathrm{~cm}^{-1}$ and the formation of two $-\mathrm{CH}_{2}$ - and $-\mathrm{CH}_{3}$ bands.

From the MTT absorbance values, it can be concluded that the degree of cell proliferation for the chitosan-coated Ti6Al4V group was higher than that of the control and chitosan-coated and aged groups after
96 h. Although the chitosan coating induced a proliferation of the HGF-1 cells, after the aging process their vitality decreased significantly. The general shape and growth pattern of the fibroblast cells can be seen directly from the SEM micrographs (Figure 6). After $96 \mathrm{~h}$ of culturing, the cells attached to all the different surfaces; the cells on the control samples were more flattened than on the other surfaces, with a broader contact area. In contrast, the cells on the chitosan-coated Ti6Al4V surface had a polygonal morphology with extensions in multiple directions.

In addition, the cells on the chitosan-coated and aged surface showed a spindle-like and elongated morphology, but they did not completely adhere to the surface. From the above we can conclude that the cells cultured on the chitosan coating showed higher initial-adhesion properties with an increased number of extremities of the cell bodies when compared to the control group. Since the thermal process applied during the aging induced chemical modifications in the structure of chitosan, the attachment and proliferation of the cells were then different. However, one week of aging, which was a simulation of one year of the oral environment, did not erode the coating much and the cellular response to this surface was not significantly affected.

In an in-vitro study, in which the initial attachment of oral bacteria on $\mathrm{Ti}$ surfaces was investigated ${ }^{16}$, it was shown that comparatively large amounts of $P$. gingivalis and $A$. actinomycetemcomitans adhered to a Ti surface even after polishing. These findings indicate that there is a considerable risk of adhesion of periodontopathic bacteria on Ti implants. The adhesion of bacteria is generally influenced by the physicochemical properties of the material surface, including the surface roughness, hydrophobicity (surface wettability) and electrical charge (zeta potential) ${ }^{17}$. Generally, rough surfaces allow a greater bacterial adhesion than smooth surfaces.

For the Ti6Al4V implant material, the electrical charge of the material's surface influences the adhesion capacity of bacteria. Bacteria are generally negatively charged, as are the Ti6Al4V surfaces. In this study, although having the same charge, the bacteria adhered to the untreated Ti6Al4V control samples. This proves that Ti and its alloys were unable to prevent a bacterial adhesion in long-term oral applications.

As chitosan was used for coating the Ti6Al4V material in this study, the electrically charged interaction between chitosan and the bacteria is also another important factor for assessing the bacterial adhesion. Nevertheless, positively charged chitosan can react easily with the negatively charged molecules and particles. Therefore, an electrical attraction can be expected between the positively charged chitosan-coated surface of the Ti6Al4V and negatively charged $P$. gingivalis. However, because of its different physicochemical properties, chitosan has an antibacterial effect instead of allowing a bacterial adhesion. 
An ionic interaction between the cations due to the amino groups of chitosan and anionic parts of bacterial cell walls such as phospholipids and carboxylic acids was proposed as the mechanism for the antimicrobial activity of chitosan. ${ }^{18}$

It was reported that the antimicrobial effect between chitosan and bacteria was related to the following probable mechanisms: in the case of gram-positive bacteria, chitosan on the surfaces of cell walls forms a polymeric membrane which inhibits the food ingestion into the cells. Therefore, the cells cannot get food. In the case of gram-negative bacteria (such as E. coli), low-molecular-weight chitosan can pass into the cells easier; there it breaks the cell metabolism, forms flocculation and kills the bacteria by changing their physiological activities. ${ }^{19}$ In this study, the antibacterial effect of chitosan against $P$. gingivalis can be explained with the above mechanisms. On the other hand, bacterial inhibition was not provided on the samples that were exposed to the aging process, which can be explained with the chemical effects of the aging process.

In summary, chitosan was successfully applied to the Ti alloy and the aging process did not significantly erode the coating material. The chitosan coating allowed the adhesion and proliferation of human gingival fibroblast cells and it showed a high level of cytocompatibility while preventing the growth of the $P$. gingivalis bacteria. As determined with the FTIR studies, a one-week aging process, simulating a one-year oral environment, altered the chemical structure of the chitosan coating. The cell attachment decreased slightly; however, the coating was not able to perform its antibacterial activity after the aging process even though it was still better than the uncoated metal.

\section{Acknowledgements}

This research was supported by TUBITAK (the Scientific and Technological Research Council of Turkey) through project 111S515. The authors would also like to thank the Advanced Technology Research and Application Center at the Selcuk University for providing the resources (the cell culture and SEM facilities) necessary for the completion of this work.

\section{REFERENCES}

${ }^{1}$ F. Schwarz, M. Herten, M. Sager, K. Bieling, A. Sculean, J. Becker, Clinical Oral Implants Research, 18 (2007), 161-170, doi:10.1111/ j.1600-0501.2007.01482.x

${ }^{2}$ H. L. Myshin, J. P. Wiens, Journal of Prosthodontic Dentistry, 94 (2005), 440-444, doi:10.1016/j.prosdent.2005.08.021

${ }^{3}$ P. Schupbach, R. Glauser, Journal of Prosthodontic Dentistry, 97 (2007), 15-25, doi:10.1016/S0022-3913(07)60004-3

${ }^{4}$ Y. A. D. Sitbon, Epithelial cells attachment on five different dental implant abutment surface, $\mathrm{PhD}$ Dissertation, University of Iowa, Iowa, USA, 2009

${ }^{5}$ Å. Leonhardt, G. Dahlén, European Journal of Oral Science, 103 (1995) 6, 382-387, doi:10.1111/j.1600-0722.1995.tb01861.x

${ }^{6}$ B. D. Ratner, A. S. Hoffman, F. J. Schoen, J. E. Lemons, Biomaterials Science: an Introduction to Materials in Medicin, Academic Press, San Diego, CA, USA 1996

${ }^{7}$ F. Ezoddini-Ardakani, A. N. Azam, S. Yassaei, F. Fatehi, G. Rouhi, Health, 3 (2011), 200-205, doi:10.4236/health.2011.34036

${ }^{8}$ Y. Yuan, B. M. Chesnutt, L. Wright, W. O. Haggard, J. D. Bumgardner, Journal of Biomedical Materials Research, Part B, 86B (2008), 245-252, doi:10.1002/jbm.b.31012

${ }^{9}$ M. S. Gale, B. W. Darwell, Journal of Dentistry, 27 (1999) 2, 89-99, doi:10.1016/S0300-5712(98)00037-2

${ }^{10}$ X. Wang, Y. Du, J. Yang, X. Wang, X. Shi, Y. Hu, Polymer, 47 (2006), 6738-6744, doi:10.1016/j.polymer.2006.07.026

${ }^{11}$ P. Renoud, B. Toury, S. Benayoun, G. Attik, B. Grosgogeat, PloS One, e39367, 7 (2012), 1-10, doi:10.1371/journal.pone.0039367

${ }^{12} \mathrm{~T}$. Albrektsson, A. Wennerberg, International Journal of Prosthodontics, 17 (2004) 5, 544-564

${ }^{13}$ E. A. El-Hefian, M. M. Nasef, A. H. Yahaya, E-Journal of Chemistry, 9 (2012), 510-516, doi:10.1155/2012/285318

${ }^{14}$ B. Burnat, M. Walkowiak-Przybyło, T. Błaszczyk, L. Klimek, Acta Bioengineering and Biomechanics, 15 (2013), 87-95, doi:10.5277/ abb130111

${ }^{15}$ L. Qi, Z. Xu, X. Jiang, C. Hu, X. Zou, Carbohydrate Research, 339 (2004), 2693-2700, doi:10.1016/j.carres.2004.09.007

${ }^{16}$ M. Yoshinari, Y. Oda, T. Kato, K. Okuda, A. Hirayama, Journal of Biomedical Materials Research, 52 (2000), 388-394, doi:10.1002/ 1097-4636(200011)52:2<388::AID-JBM20>3.0.CO;2-E

${ }^{17}$ M. Egawa, T. Miura, T. Cato, A. Saito, M. Yoshinari, Dental Materials Journal, 32 (2013), 1001-106, doi:10.4012/djm.2012-156

${ }^{18}$ G. İkinci, S. Şenel, H. Akıncıbay, S. Kaş, S. Erciş, C. G. Wilson, A. A. Hincal, International Journal of Pharmaceutics, 235 (2002), 121-127, doi:10.1016/S0378-5173(01)00974-7

${ }^{19}$ L. Y. Zheng, J. F. Zhu, Carbohydrate Polymers, 54 (2003), 527-530, doi:10.1016/j.carbpol.2003.07.009 